\title{
Studies on Growth and Development of Helicoverpa armigera (Hub.) on Various Hosts and Artificial Diet under Laboratory Conditions
}

\author{
Lomash Kumar ${ }^{1}$, R.S. Bisht ${ }^{1}$, Hem Singh ${ }^{2 *}$ and Mohit Kumar ${ }^{3}$ \\ ${ }^{1}$ Department of Entomology, ${ }^{3}$ Department of Horticulture, Govind Ballabh Pant University of \\ Agriculture and Technology, Pantnagar- 263145, Uttarakhand, India \\ ${ }^{2}$ Department of Entomology, S.V.B. Patel University of Agriculture and Technology, \\ Meerut- 250110, India \\ *Corresponding author
}

\begin{abstract}
A B S T R A C T
Present investigation was carried out on five different diets (Chickpea soaked grains, Tomato fruits, Pigeon pea soaked grains, Pea soaked grains and Artificial diet) to evaluate the feeding response on growth and development parameters against Helicoverpa armigera (Hub.) at controlled conditions at $27-29^{\circ} \mathrm{C}$ temperature, $55-75 \%$ relative humidity and photoperiod of 10-14 (L:D)h. Growth and development was compared as different parameters such as larval period, pre-pupal period, pupal period, percent pupation, pupal weight and percent adult emergence along with preoviposition period, oviposition period, post oviposition period, fecundity, longevity and sex ratio. Growth indices values were also studied on different hosts also. The results revealed that artificial diet had relatively shorter larval period, pre-pupal period and percent pre-pupa as compared to other diets experimented followed by chickpea (grains). Longer duration of larval instars in general on the contrary has been observed with tomato (fruits). Moreover, pre-pupal and pupal weight was also observed highest on artificial diet followed by chickpea and lowest on tomato. Percent pupation and adult emergence was also recorded highest in artificial diet followed by chickpea and least on tomato. Effect of different tested diets on pre-oviposition, oviposition, postoviposition and fecundity was also found better in artificial diet followed by chickpea, tomato, pea and pigeonpea. However, the sex ratio obtained after feeding the larvae on different diets did not differ significantly. The growth index, larval-pupal index, pupal weight index, survival index and ovipositional index values were found highest with artificial diet followed by chickpea, pea and pigeonpea while it was the lowest on tomato. Therefore, from the present experiment it was concluded that artificial diet to be proved more effective in all parameters. Also it would be helpful for mass rearing of $H$. armigera on different food substrates which ultimately be beneficial for making better management practices of this noxious pest.
\end{abstract}

\section{Introduction}

Helicoverpa armigera (Hubner) (Lepidopltera: Noctuidae), a pest of national importance in India, is one of the major limiting factor in the successful cultivation of chickpea (Sharma et al., 2006). However, the insect also causes economic losses to several other crops like tomato, cotton, pigeonpea, sunflower, marigold, groundnut, okra, beans etc. because of its highly polyphagous nature. Globally, few insect pests cause as much 
economic crop losses as does Helicoverpa armigera, better known under its previous name Heliothis armigera (Reed and Pawar, 1982).

$H$. armigera is a prolific, widespread pest, feeds on at least 180 plant species, spread across 47 botanical families. Studies determined the hosts plants of $H$. armigera in India (60 cultivated and 67 wild plants) by Karim (2000), Africa by Pearson (1958), Australia by Zalucki et al., (1986) and in New Zealand by Thanee (1987). In India, this pest has been reported to cause $32-100 \%$ damage to chickpea pods, while yield losses has been estimated to the extent of 4.2 to $77 \%$ (Ujagir and Khare, 1987 and Singh et al., 1990).

Control and management of Helicoverpa armigera is very difficult due to its high mobility, high fecundity, high survival rate, short life span and ability to develop resistance against pesticides (Drake, 1991). Therefore, to prepare the best integrated pest management strategy of $H$. armigera, it is necessary to know how insects grow and develop (life history, behavior, feeding habits and their susceptibility and resistance to chemical and biological pesticides).

For example, knowledge of the hormonal control of insect metamorphosis led to the development of a new class of insecticides called insect growth regulators (IGR). The insect growth regulators are very selective in the insects they affect. Based upon information about insect growth rates and development at various stages (egg, larvae, prepupal, pupal and adults), relative to temperature, humidity etc. computer models can be used to predict when insects will be most abundant during the growing season and consequently, when crops are most at risk and what kind control measures should be applied. So, to implement the management strategies of IPM (Integrated Pest Management) with response to growth, development and survival the present investigation has been undertaken.

\section{Materials and Methods}

The present investigation was carried out at Plant Health Clinic Laboratory, College of Agriculture, G.B. Pant University of Agriculture and Technology, Pantnagar with laboratory temperature $27-29^{\circ} \mathrm{C}$, the relative humidity was $55-75 \%$ and available photoperiod was 14-10 (L:D)h.

Five types of diets selected for this experiment were (1) Chickpea soaked grains in water for 8 hours (2) Pigeon pea soaked grains in water for 8 hours (3) Pea soaked grains in water for 8 hours (4) Tomato fruits and (5) Artificial diet prepared according to format given by Prasad et al., (2008);

\section{Preparation of artificial diet}

Artificial diet for $H$. armigera was prepared in three steps such as follows:

\section{Step I: Preparation of mixture A}

The following ingredients were mixed with $390 \mathrm{ml}$ of water: 105 gm chickpea flour +2 gm Methyl Para Hydroxy Benzoate +1 gm Sorbic acid +0.25 gm Streptomycin $+2 \mathrm{ml}$ of $10 \%$ formaldehyde. This combination was mixed thoroughly in a blender for two minutes.

\section{Step II: Preparation of mixture B}

12.75 gm of Agar-Agar was boiled in $390 \mathrm{ml}$ of water. This gave mixture B.

\section{Step III: Preparation of mixture C}

Mixture A and B were combined and blended for 1 minute and then $10 \mathrm{gm}$ Yeast $+3.25 \mathrm{gm}$ Ascorbic acid +2 Multiple Vitamin capsule + 
2 Vitamin E capsules were added and was mixed again by using a blender for one minute. This provided artificial diet was poured in a flat trey and small squares were cut by knife and the diet is ready to carry out the experiments.

For maintaining the culture of the test insect, $H$. armigera, adults were collected from the unsprayed field and kept inside the wired cylindrical cage of $115 \mathrm{~cm}$. length and $38 \mathrm{~cm}$. dia covered with muslin cloth. Ten pairs of male and female were released in each cage by providing $10 \%$ sugar solution soaked in cotton swab and the insect was allowed for egg laying. The eggs laid on the muslin cloth were collected with the help of moist camel hair brush and then transferred to the test experimental diets.

To study the growth and development, the newly hatched eggs into neonatal larvae were transferred with the help of a moist camel hair brush to respective host viz., Chick pea (soaked grains), Tomato (fruits), Pigeon Pea (soaked grains), Pea (soaked grains) and Artificial diet placed on a moist filter paper kept inside petri dishes $(13 \mathrm{~cm}$. dia.). The neonatal larvae appear like extremely minute thread like body with black head. These neonatal larvae were transferred to another vials containing five different diets. The experiment for each diet was replicated thrice having 10 neonates in each replicate. From third instar onwards when larvae grew in size (8-13mm long), they were kept individual to avoid cannibalism and provided with respective diets. Diet was changed daily. When $6^{\text {th }}$ instar larvae entered into pupal stage kept in separate plastic vials having autoclaved sand at bottom. The pupae were identified for different sexes by examining the distance between the genital pore and anal pore. After emerging adult moth from each pupa leaves an empty, thin, papery brown shell. These adult moths were transferred to another rearing chamber of 50-60 cu. $\mathrm{cm}$ plastic container. It is used as oviposition chamber. Mouth of container was covered with muslin cloth. One pair of adult moths was released into the container. Two medium sized Petri-dishes containing cotton swab soaked in $10 \%$ honey solution were placed in the chamber to provide food for adults. Minute greenish colored eggs were seen at the inner surface of cloth at about $2^{\text {nd }}$ to $4^{\text {th }}$ day. Theses eggs were collected and counted for fecundity of the test insects.

The effect of host plant on moulting, larval period, prepupal period, percentage prepupation, pupal period, pupal weight, percentage pupation, percent adult emergence, fecundity and adult longevity (male and female) was observed and statistically analyzed by using the following formulae, as prescribed by Shanower et al., (1997).

Growth index $($ G.I. $)=\frac{\text { Percentage } \quad \text { pupation }}{\text { Larval } \text { period }}$

\section{Larval-pupa index =}

Av. larval period (days) on standard host * + Av. pupal period (days) on standard host

\section{Pupal-weight index =}

Av. pupal weight (mg) on test host

Av. pupal weight (mg) on standard host

\section{Adult index =}

\begin{tabular}{clll} 
Av. adult (male/fema le) longevity on test host \\
\hline Av. adult (male/fema le) longevity on standard host
\end{tabular}

\section{Survival index $=$}

\begin{tabular}{l} 
No. of adults emerged from the \\
same number of larvae on test host \\
\hline No. of adults emerged from the same \\
number of larvae on standard host
\end{tabular}




\section{Ovipositional index $=$}

\begin{tabular}{l} 
Av. no. of eggs laid by adults emerged \\
from the larvae reared on test host \\
\hline Av. no. of adults emerged from the same \\
number of larvae on standard host
\end{tabular}

\section{Results and Discussion}

In the present investigation data collected on the effect of different hosts on growth and development of $H$. armigera are presented in Table 1 and Figure 1, 2 and 3.

In laboratory the larva passed through six instars when the range of temperature was 27 $29^{\circ} \mathrm{C}$ and that of relative humidity 55 to $75 \%$. A perusal of data revealed that the growth and development of different instar larvae of $H$. armigera significantly influenced when they were fed on different hosts.

\section{Larval period (Table 1, Figure 1)}

The results revealed comparison between the growth and developmental parameters of larvae on five different diets in laboratory. It is reported that the average longest larval period of 19.23 days was attained by larvae feed on tomato (fruits), followed by 17.07 days on pigeonpea (grains), 15.53 days on chickpea (grains) and 14.60 days on pea (grains).

The shortest larval period of 11.27 on the contrary, was observed with artificial diet. All the food materials fed to the larvae were found statistically significant in terms of total larval period. The total larval period of 15.53 and 19.23 days, respectively of $H$. armigera on chickpea and tomato are in close agreement with that of Devi and Singh, (2004) and Gupta et al., (2004) who reported 14.86 and 16.17 days of larval periods of $H$. armigera on chickpea and tomato, respectively.
Prepupal and pupal period (Table 1 and Figure 1)

Attainment of longest average prepupal period of 2.27 days was recorded on tomato fruits which was statistically different from rest of the hosts. The host, pigeonpea appeared as the next host after tomato whereas the shortest average prepupal period was recorded with artificial diet, 1.13 days. Nevertheless, the prepupal periods on chickpea, pigeonpea and pea were found statistically at par with each other.

Likewise the pupal period was also found to be longest 11.57 days on tomato while the shortest pupal period of 9.53 days was observed with artificial diet. Earlier, Devi and Singh (2004) observed shortest pupal period of $H$. armegera to the extent of 10.31days on pea followed by pigeonpea (10.63 days) and tomato (11.34 days). Shahid et al., (1990) on the contrary observed shortest pupal period of 9.38 days on chickpea.

\section{Prepupal and pupal weight (Table 1 and} Figure 1)

Considering the results about weight of prepupae and pupae exhibited significant differences among different diets. They reported maximum weight of prepupae and pupae viz., 362.34 and $321.33 \mathrm{mg}$ when the larvae were fed on artificial diet followed by chickpea, pigeon pea and pea. On the other hand the lowest prepupal and pupal weight of 280.33 and $237.77 \mathrm{mg}$ respectively was observed when larvae were fed on tomato. Therefore, data reveals that the artificial diet appeared to the most favourable diet for increasing weight of prepuae and pupae of $H$. armegera. These results are in conformity with the recent report of Tulsi et al., (2008) who observed maximum weight of prepupal (362.34 and $321.33 \mathrm{mg}$ respectively) when the larvae were fed on artificial diet. 


\section{Int.J.Curr.Microbiol.App.Sci (2017) 6(12): 1627-1637}

Table.1 Effect of different hosts on the growth and development of Helicoverpa armigera

\begin{tabular}{|c|c|c|c|c|c|c|c|c|c|c|c|c|c|c|}
\hline \multirow{2}{*}{$\begin{array}{l}\text { Host } \\
\text { (Diet) }\end{array}$} & \multicolumn{6}{|c|}{ Duration of larval instar (days) } & \multirow{2}{*}{$\begin{array}{l}\text { Larval } \\
\text { Period } \\
\text { (days) }\end{array}$} & \multirow{2}{*}{$\begin{array}{l}\text { Pre- } \\
\text { pupal } \\
\text { period } \\
\text { (days) }\end{array}$} & \multirow{2}{*}{$\begin{array}{l}\text { Percent } \\
\text { Pre- } \\
\text { pupa }\end{array}$} & \multirow{2}{*}{$\begin{array}{l}\text { Pre } \\
\text { pupal } \\
\text { weight } \\
\text { (mg) }\end{array}$} & \multirow{2}{*}{$\begin{array}{l}\text { Pupal } \\
\text { period } \\
\text { (days) }\end{array}$} & \multirow{2}{*}{$\begin{array}{l}\text { Percent } \\
\text { pupatio } \\
\text { n }\end{array}$} & \multirow{2}{*}{$\begin{array}{l}\text { Pupal weight } \\
\text { (mg) }\end{array}$} & \multirow{2}{*}{$\begin{array}{l}\text { Percent } \\
\text { Adult } \\
\text { emergenc } \\
\text { e }\end{array}$} \\
\hline & $\mathbf{I}$ & II & III & IV & $\mathbf{V}$ & VI & & & & & & & & \\
\hline $\begin{array}{l}\text { Chickpea } \\
\text { (Grain) }\end{array}$ & $\begin{array}{c}2.93 \\
(1.00-3.20) \\
* * *\end{array}$ & $\begin{array}{c}2.70 \\
(2.00-3.10) \\
* * *\end{array}$ & $\begin{array}{c}2.53 \\
(1.5-3.25) \\
* *\end{array}$ & $\begin{array}{c}2.27 \\
(1.5-3.00) \\
* * *\end{array}$ & $\begin{array}{c}1.67 \\
(1.25-2.85) \\
* * *\end{array}$ & $\begin{array}{c}3.43 \\
(1.90-4.10) \\
* * *\end{array}$ & $\begin{array}{c}15.53 \\
(9.15-19.50) \\
* * *\end{array}$ & $\begin{array}{c}1.83 \\
(1.00- \\
2.25)^{* *}\end{array}$ & $\begin{array}{c}93.58 \\
(75.44)^{*}\end{array}$ & $\begin{array}{c}389.33 \\
(285.56- \\
\underset{* *}{425.21)}\end{array}$ & $\begin{array}{c}10.78 \\
(7.00-11.50) \\
* * *\end{array}$ & $\begin{array}{c}85.67 \\
(67.87)\end{array}$ & $\begin{array}{c}346.03 \\
(225.1-395.0) \\
\text { *** }\end{array}$ & $\begin{array}{c}81.87 \\
(64.88)^{*}\end{array}$ \\
\hline $\begin{array}{l}\text { Tomato } \\
\text { (Fruit) }\end{array}$ & $\begin{array}{c}3.80 \\
(2.5-4.50)\end{array}$ & $\begin{array}{c}3.27 \\
(2.75-4.25)\end{array}$ & $\begin{array}{c}2.80 \\
(2.25- \\
3.50)\end{array}$ & $\begin{array}{l}2.57 \\
(2.00- \\
3.20)\end{array}$ & $\begin{array}{c}2.40 \\
(2.10-3.80)\end{array}$ & $\begin{array}{c}4.40 \\
(3.25-4.50)\end{array}$ & $\begin{array}{c}19.23 \\
(14.85- \\
23.75)\end{array}$ & $\begin{array}{c}2.27 \\
(1.25- \\
2.50)\end{array}$ & $\begin{array}{c}81.77 \\
(64.76)\end{array}$ & $\begin{array}{c}280.33 \\
(175.11- \\
320.25)\end{array}$ & $\begin{array}{c}11.57 \\
(8.25-12.50)\end{array}$ & $\begin{array}{c}75.08 \\
(60.08)\end{array}$ & $\begin{array}{c}237.77 \\
(125.25- \\
281.50)\end{array}$ & $\begin{array}{c}70.61 \\
(57.20)\end{array}$ \\
\hline $\begin{array}{c}\text { Pigeonpea } \\
\text { (Grain) }\end{array}$ & $\begin{array}{c}3.83 \\
(2.5-4.25)\end{array}$ & $\begin{array}{c}2.50 \\
(2.10-3.00)\end{array}$ & $\begin{array}{c}2.43 \\
(1.75- \\
3.00)\end{array}$ & $\begin{array}{l}2.40 \\
(1.25- \\
3.00)\end{array}$ & $\begin{array}{c}2.43 \\
(1.75-3.00)\end{array}$ & $\begin{array}{c}3.47 \\
(2.5-3.50)\end{array}$ & $\begin{array}{c}17.07 \\
(11.85- \\
19.75)\end{array}$ & $\begin{array}{l}2.03 \\
(1.00- \\
2.25)\end{array}$ & $\begin{array}{c}83.67 \\
(66.21)\end{array}$ & $\begin{array}{c}364.00 \\
(184.85- \\
417.30)\end{array}$ & $\begin{array}{c}10.37 \\
(7.00-11.50)\end{array}$ & $\begin{array}{c}76.95 \\
(61.36)\end{array}$ & $\begin{array}{l}319.53 \\
(162.0- \\
350.55)\end{array}$ & $\begin{array}{c}74.29 \\
(59.56)\end{array}$ \\
\hline $\begin{array}{c}\text { Pea } \\
\text { (Grain) }\end{array}$ & $\begin{array}{c}2.40 \\
(1.75-3.20)\end{array}$ & $\begin{array}{c}2.27 \\
(1.75-2.80)\end{array}$ & $\begin{array}{c}2.23 \\
(1.90- \\
2.50)\end{array}$ & $\begin{array}{l}2.17 \\
(1.90- \\
2.50)\end{array}$ & $\begin{array}{c}2.23 \\
(2.00-2.75)\end{array}$ & $\begin{array}{c}3.30 \\
(2.25-3.00)\end{array}$ & $\begin{array}{c}14.60 \\
(11.35- \\
17.00)\end{array}$ & $\begin{array}{l}1.97 \\
(1.00- \\
2.00)\end{array}$ & $\begin{array}{c}87.98 \\
(69.97)\end{array}$ & $\begin{array}{c}327.33 \\
(250.30- \\
425.00)\end{array}$ & $\begin{array}{c}10.31 \\
(7.50-11.00)\end{array}$ & $\begin{array}{c}78.24 \\
(62.24)\end{array}$ & $\begin{array}{c}294.37 \\
(195.55- \\
328.30)\end{array}$ & $\begin{array}{c}75.40 \\
(60.29)\end{array}$ \\
\hline $\begin{array}{c}\text { Artificial } \\
\text { Diet }\end{array}$ & $\begin{array}{c}1.77 \\
(1.00-2.25)\end{array}$ & $\begin{array}{c}1.90 \\
(1.25-2.75)\end{array}$ & $\begin{array}{c}1.73 \\
(1.25- \\
3.00)\end{array}$ & $\begin{array}{c}1.80 \\
(1.25- \\
3.00)\end{array}$ & $\begin{array}{c}1.77 \\
(1.25-3.25)\end{array}$ & $\begin{array}{c}2.30 \\
(1.75-3.50)\end{array}$ & $\begin{array}{c}11.27 \\
(7.75-17.75)\end{array}$ & $\begin{array}{c}1.13 \\
(1.00- \\
1.50)\end{array}$ & $\begin{array}{c}95.93 \\
(78.70)\end{array}$ & $\begin{array}{c}408.67 \\
(250.33- \\
451.25)\end{array}$ & $\begin{array}{c}9.53 \\
(6.00-10.00)\end{array}$ & $\begin{array}{c}91.86 \\
(73.55)\end{array}$ & $\begin{array}{l}377.60 \\
(205.3- \\
350.10)\end{array}$ & $\begin{array}{c}83.46 \\
(66.09)\end{array}$ \\
\hline $\mathrm{SEm} \pm$ & 0.95 & 0.84 & 0.86 & 0.10 & 0.99 & 0.53 & 0.26 & 0.94 & 1.74 & 4.86 & 0.13 & 1.19 & 4.69 & 1.06 \\
\hline $\begin{array}{l}\mathrm{CD} \\
(\mathrm{P}=0.05)\end{array}$ & 0.31 & 0.27 & 0.28 & 0.33 & 0.32 & 0.17 & 0.87 & 0.31 & 5.69 & 15.85 & 0.43 & 3.89 & 15.29 & 3.46 \\
\hline
\end{tabular}

Data in parentheses indicate angular transformed values ${ }^{* *}$ Data in parentheses indicate the range 
Table.2 Effect of different hosts on preoviposition, oviposition, post oviposition periods, fecundity, longevity and sex ratio of $H$. armigera

\begin{tabular}{|c|c|c|c|c|c|c|c|}
\hline \multirow[t]{2}{*}{ Host } & \multirow{2}{*}{$\begin{array}{l}\text { Pre oviposition } \\
\text { period (days) }\end{array}$} & \multirow{2}{*}{$\begin{array}{c}\text { Oviposition } \\
\text { period (days) }\end{array}$} & \multirow{2}{*}{$\begin{array}{l}\text { Post oviposition } \\
\text { period (day) }\end{array}$} & \multirow{2}{*}{$\begin{array}{c}\text { Fecundity } \\
\text { (egg/female) }\end{array}$} & \multicolumn{2}{|c|}{ Longevity (days) } & \multirow{2}{*}{$\begin{array}{l}\text { Sex Ratio } \\
\text { (M:F) }\end{array}$} \\
\hline & & & & & Male & Female & \\
\hline $\begin{array}{c}\text { Chickpea } \\
\text { (Grain) }\end{array}$ & $\begin{array}{c}3.11 \\
(2.50-4.00)^{*}\end{array}$ & $\begin{array}{c}5.57 \\
(4.25-6.00)\end{array}$ & $\begin{array}{c}2.08 \\
(1.75-2.50)\end{array}$ & $\begin{array}{c}773.34 \\
(325-871)\end{array}$ & $\begin{array}{c}7.71 \\
(5.20-8.00)\end{array}$ & $\begin{array}{c}10.96 \\
(7.50-11.00)\end{array}$ & $1: 1.7$ \\
\hline $\begin{array}{l}\text { Tomato } \\
\text { (Fruit) }\end{array}$ & $\begin{array}{c}2.66 \\
(2.50-3.25)\end{array}$ & $\begin{array}{c}4.71 \\
(3.50-5.50)\end{array}$ & $\begin{array}{c}1.42 \\
(1.25-1.75)\end{array}$ & $\begin{array}{c}556.67 \\
(218-621)\end{array}$ & $\begin{array}{c}6.65 \\
(4.50-7.25)\end{array}$ & $\begin{array}{c}8.79 \\
(5.75-10.00)\end{array}$ & $1: 1.2$ \\
\hline $\begin{array}{l}\text { Pigeonpea } \\
\text { (Grain) }\end{array}$ & $\begin{array}{c}2.61 \\
(2.00-3.50)\end{array}$ & $\begin{array}{c}4.55 \\
(3.50-6.00)\end{array}$ & $\begin{array}{c}1.53 \\
(1.25-2.50)\end{array}$ & $\begin{array}{c}628.66 \\
(317-745)\end{array}$ & $\begin{array}{c}6.59 \\
(5.50-7.50)\end{array}$ & $\begin{array}{c}8.69 \\
(6.00-10.25)\end{array}$ & $1: 1.4$ \\
\hline $\begin{array}{c}\text { Pea } \\
\text { (Grain) }\end{array}$ & $\begin{array}{c}2.62 \\
(1.75-3.00)\end{array}$ & $\begin{array}{c}5.19 \\
(3.50-5.50)\end{array}$ & $\begin{array}{c}1.98 \\
(1.00-2.50)\end{array}$ & $\begin{array}{c}744.33 \\
(385-794)\end{array}$ & $\begin{array}{c}7.52 \\
(4.50-8.00)\end{array}$ & $\begin{array}{c}9.77 \\
(6.50-10.50)\end{array}$ & $1: 1.6$ \\
\hline Artificial Diet & $\begin{array}{c}3.33 \\
(2.50-4.25)\end{array}$ & $\begin{array}{c}5.78 \\
(3.00-6.00)\end{array}$ & $\begin{array}{c}2.13 \\
(1.75-3.00)\end{array}$ & $\begin{array}{c}784.66 \\
(422-886)\end{array}$ & $\begin{array}{c}8.18 \\
(6.00-9.25)\end{array}$ & $\begin{array}{c}11.12 \\
(8.00-12.50)\end{array}$ & 1: 1.8 \\
\hline SEm \pm & 0.15 & 0.22 & 0.17 & 87.18 & 0.26 & 0.21 & - \\
\hline $\mathrm{CD}(\mathrm{P}=0.05)$ & 0.49 & 0.72 & 0.57 & 284.15 & 0.85 & 0.69 & - \\
\hline
\end{tabular}


Table.3 Growth indices of $H$. armigera on different hosts

\begin{tabular}{|c|c|c|c|c|c|c|c|}
\hline \multirow[t]{2}{*}{ Host } & \multirow{2}{*}{$\begin{array}{l}\text { Growth } \\
\text { Index }\end{array}$} & \multirow{2}{*}{$\begin{array}{c}\text { Larval pupal } \\
\text { index }\end{array}$} & \multirow{2}{*}{$\begin{array}{l}\text { Pupal weight } \\
\text { index }\end{array}$} & \multirow{2}{*}{$\begin{array}{c}\text { Survival } \\
\text { index }\end{array}$} & \multirow[t]{2}{*}{ Ovipositional index } & \multicolumn{2}{|c|}{ Adult index } \\
\hline & & & & & & Male & Female \\
\hline $\begin{array}{c}\text { Chickpea } \\
\text { (Grain) }\end{array}$ & 5.49 & 1.000 & 1.000 & 1.000 & 1.000 & 1.000 & 1.000 \\
\hline $\begin{array}{l}\text { Tomato } \\
\text { (Fruit) }\end{array}$ & 3.99 & 0.853 & 0.687 & 0.863 & 0.718 & 0.862 & 0.801 \\
\hline $\begin{array}{c}\text { Pigeonpea } \\
\text { (Grain) }\end{array}$ & 4.41 & 0.956 & 0.923 & 0.879 & 0.813 & 0.855 & 0.791 \\
\hline $\begin{array}{c}\text { Pea } \\
\text { (Grain) }\end{array}$ & 5.39 & 1.053 & 0.851 & 0.891 & 0.962 & 0.975 & 0.891 \\
\hline Artificial Diet & 8.14 & 1.261 & 1.091 & 1.012 & 1.015 & 1.061 & 1.005 \\
\hline $\begin{array}{c}\text { SEm } \pm \\
\mathrm{CD}(\mathrm{P}=0.05)\end{array}$ & $\begin{array}{l}0.12 \\
0.40\end{array}$ & & & & & & \\
\hline
\end{tabular}

Fig.1 Effect of different hosts on the growth and development of Helicoverpa armigera

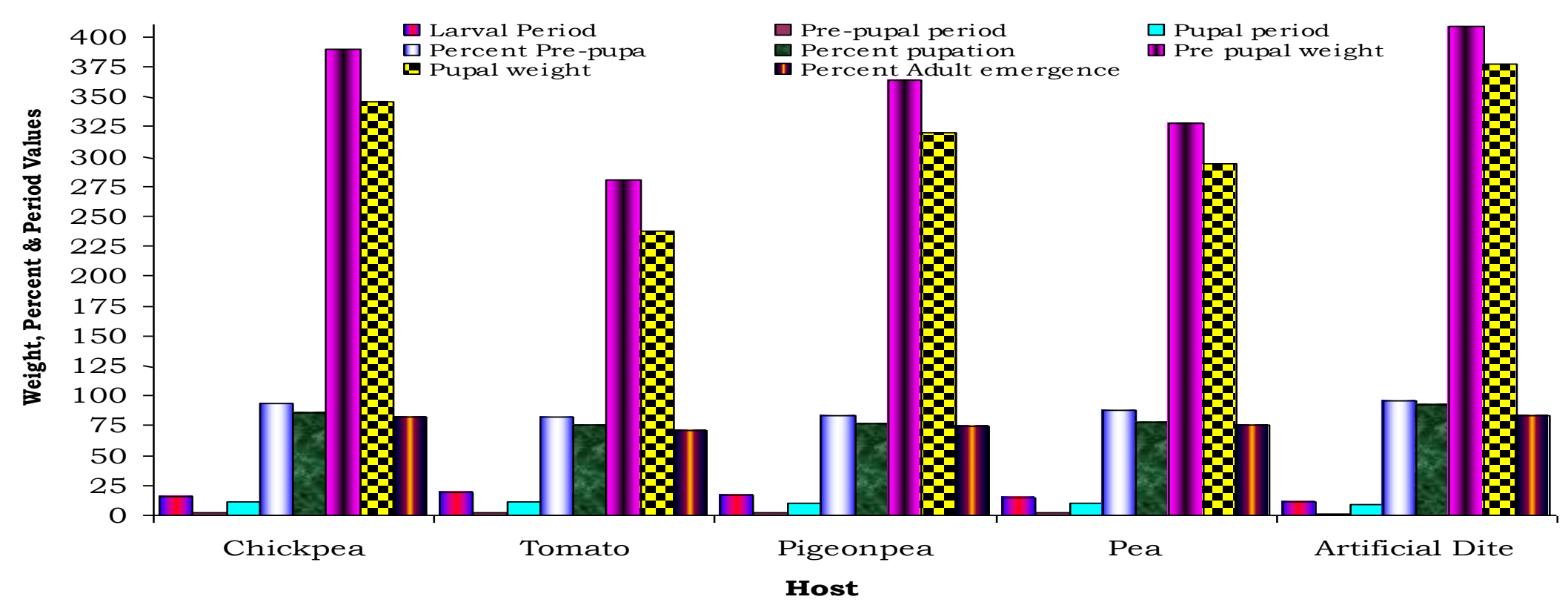


Fig.2 Effect of different hosts on preoviposition, oviposition, post oviposition periods and longevity of $H$. armigera

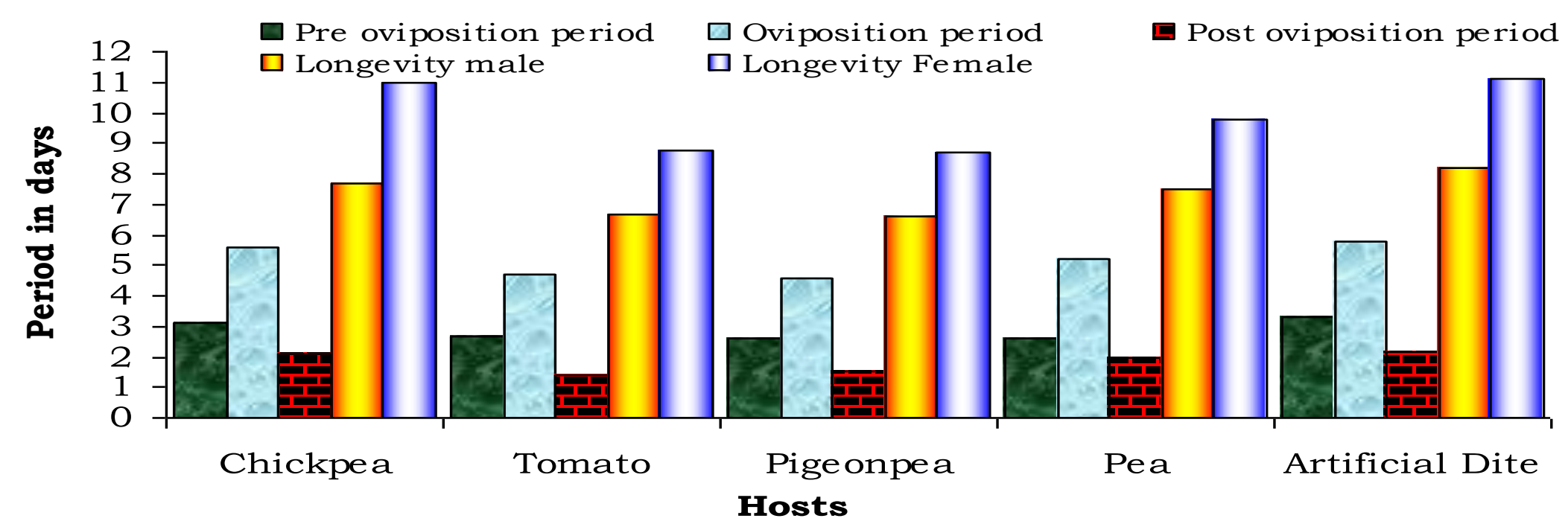

Fig.3 Growth indices of $H$. armigera on different hosts

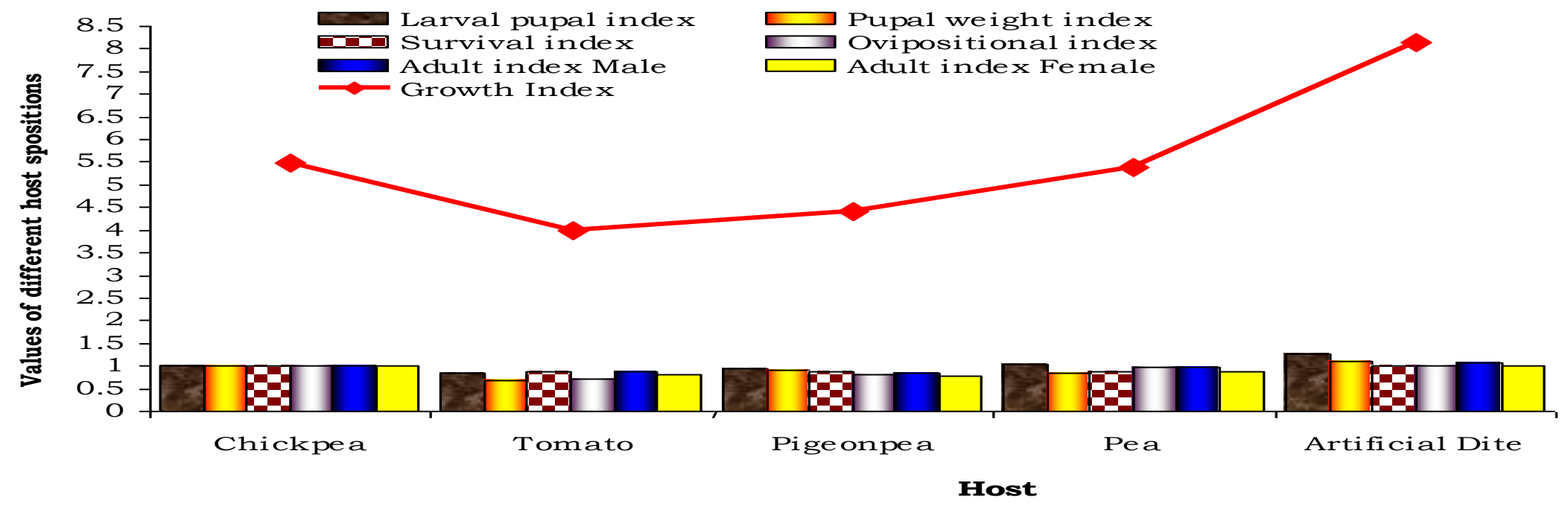


Pre-pupal and pupal percent (Table 1 and Figure 1)

It is evident that the highest average pre-pupal and pupal percent of $95.3 \%$ and $91.86 \%$, respectively was recorded on artificial diet. In comparison, the average percent prepupae and pupae was lowest on Tomato $81.77 \%$ and $75.08 \%$, respectively. Chickpea was observed as the next favourable host with average prepupal and pupal percent of $93.58 \%$ and $85.67 \%$, respectively followed by pea (87.98\% and $78.24 \%$, respectively) which were statistically at par with pigeonpea $(83.67 \%$ and $76.95 \%)$. These results were in conformation with the work of Devi and Singh, 2004 who reported percent pupation in $H$. armegera on tomato was to the extent of $75.05 \%$ but contradictory to the finding of Parihar and Singh (1992) who reported $39 \%$ pupation of chickpea pod borer on tomato.

Percent adult emergence (Table 1 and Figure 1)

Data presented in the Table 1 shows that there was maximum adult emergence of $83.46 \%$ recorded when the larvae of $H$. armigera fed on artificial diet. The next suitable host was chickpea, with $81.87 \%$ adult emergence followed by the pea $(75.40 \%)$ which was found statistically at par with pigeonpea and tomato (74.29\% and $70.61 \%$, respectively). Devi and Singh (2004) also reported highest adult emergence $82.43 \%$ of chickpea pod borer on chickpea but lowest $62.17 \%$ on khamen akhabi.

Also the results shows that the larvae of $H$. armigera fed on artificial diet not only showed higher percent emergence but also longest adult life span of 8.18 days in male and 11.12 days in female. Moreover the adults emerged from artificial diet were more robust and larger than adults emerged from other hosts.
Preovipoisition, oviposition and postoviposition periods (Table 2 and Figure 2)

The preovipoisition, oviposition and postoviposition periods of the moth were also observed and resulted longer (3.33, 5.78 and 2.13 days, respectively) when the larvae fed on artificial diet followed by chickpea (3.11, 5.57 and 2.08 days, respectively), pea (2.62, 5.19 and 1.98 days, respectively) and pigeonpea (2.61, 4.55 and 1.53 days, respectively). The shortest preoviposition, oviposition and postoviposition periods of 2.66, 4.71 and 1.42 days, respectively were recorded when the larvae fed with tomato (fruits).

\section{Fecundity (Table 2 and Figure 2)}

Observations recorded on number of eggs laid per female were found highest with artificial diet (784.66 eggs/female) and that of lowest on tomato (556.67 eggs/female). Highest fecundity in $H$. arimegra has also been reported by Tulsi et al., (2008) when the larvae were fed on artificial diet (521egg/female). Devi and Singh (2004) however reported highest fecundity on chickpea (772.17eggs/female) and lowest on khamen akhabi (417 eggs/female).

\section{Sex ratio (Table 2 and Figure 2)}

Considering the effect of different larval diets on the sex ratio of chick pod borer, it was evident that population of females outnumbered the males in all the five treatments i.e. chickpea, tomato, pigeonpea, pea and artificial diet. The highest sex ratio of 1:1.8 was obtained with artificial diet followed by 1:1.7, 1:1.6 and 1:1.4 with chickpea, pea and pigeonpea, respectively. Whereas the larval diet of tomato fruits resulted lowest sex ratio of 1:1.2. Nevertheless, statistically there was no 
significant difference among all the diets. The present findings are in accordance with Tulsi et al., (2008) who also reported highest sex ratio on artificial diet. Devi and Singh (2004) however, reported highest proportion of female in the population of $H$. armigera on chickpea diet.

\section{Growth indices values on different hosts (Table 3 and Figure 3)}

The data depicted in the table indicated that the highest growth index of 8.14 was recorded with artificial diet which was found to be superior to rest of the diets. The next diet was chickpea (5.49) which was statistically at par with pea (growth indices 5.89 and 5.39 respectively), where as the lowest growth index of 3.99 was observed with tomato. These results are in conformity to the findings of Shahid et al., (1990) and Devi and Singh (2004) who obtained highest growth indices of 4.82 and 5.77 respectively when the larvae were fed on chickpea.

The larval pupal indices on tomato and pigeonpea did not exceed unity and therefore appeared to be inferior host plants as compared to chickpea. While highest larval pupal index of 1.261 was obtained on artificial diet followed by $1.053,1.000$ on pea and chickpea respectively, all of which exceed unity and were found to be superior to other hosts. Pupal index and survival index values shows that all the treatments except artificial diet (1.091 and 1.012, respectively) and chickpea (1.000 and 1.000, respectively) were of lower magnitude than unity and showed that none of the other plant species surpassed chickpea in hosts as a natural diet suitability.

Considering the results about ovipositional index and adult index which shows that except artificial diet and chickpea (1.015 and 1.000, 1.061 and 1.000 for male and 1.005 and 1.000 for female) were of lower magnitude than the unity. The present findings are in close accordance with Devi and Singh (2004) who observed the survival index, oviposition index and adult index of chickpea pod borer on different diets as 1.000, 1.000 and 1.000 respectively. On chickpea, meanwhile Gupta et al., 2004 reported a high survival percentage of $85.4 \%$ on artificial diet.

From the present studies it was concluded that artificial diet to be proved more effective in all parameters taken for $H$. armigera growth and development. Also it would be helpful for mass rearing of $H$. armigera on different food substrates which ultimately be beneficial for making better management practices of this noxious pest.

\section{References}

Devi, N.G. and T. K. Singh. 2004. Effect of different host plants on the growth and development of gram pod borer, Helicoverpa armigera (Hubner). Ind. Jour. of Ento., 66(2): 114-118.

Gupta, G. P; Birah, A and Rani, S. 2004. Development of artificial diet for mass rearing of American bollworm, Helicoverpa armigera. Indian J. of Agri. Sci. 74(10): 548-551.

Parihar, S.B.S. and Singh, O.P. 1992. Role of host plants in development and survival of Heliothis armigera (Hb.). Bull. Entomol. New Delhi. 53: 1-2, 74-78.

Prasad C.S., Prasad M., Hussain M.A., Pal R., Kumar P., Kumar L. and Singh R. 2008. Mukhye Jaivik Pertinidhiyon ka Vyavasaik Utpadan Tekneek (in Hindi: Techniques for commercial production of important bioagents). Biocontrol Laboratory, Sardar Vallabh Bhai Patel University of Agriculture and Technology, Modipuram, Meerut, 72 pp. 
Reed, W. and Pawar, C.S. 1982. Heliothis : AGloble problem. In proc. Int. Workshop Heliothis Management. ICRISAT, Patancheru, India.

Reed, W. and Pawar, C.S. 1982. Heliothis: A Global problem. In proc. Int. Workshop Heliothis Management. ICRISAT, Patancheru, India.

Shanower, T.G., Yoshida, M. and Pater, A.J., 1997. Survival, growth, fecundity and behavior of $H$. armigera on pigeonpea and two wild Cajanus species. Journal of Economic Entomology, 90(3): 837-841.
Sharma, J.P., Bhagwat, M.P., Pampapathy, G., Sharma, J.P. and Smith, T.J. 2006. Genetic Res. and Crop Evo., 53(1): 131138.

Singh, J.; Sandhu, S.S. and Singla, M.L., 1990. Ecology of Heliothis armigera (Hb.) on chickpea in Punjab. J. Ins.Sci. 3: 47-52.

Tulsi, D., Deotale, R. O., Bisane, K. D., Dawane, P. N and Bagul, R. S 2008. Performance of artificial diets on the growth and development of Helicoverpa armigera (Hubner). Journal of Entomological Research. 32(3): 249253.

\section{How to cite this article:}

Lomash Kumar, R.S. Bisht, Hem Singh and Mohit Kumar. 2017. Studies on Growth and Development of Helicoverpa armigera (Hub.) on Various Hosts and Artificial Diet under Laboratory Conditions. Int.J.Curr.Microbiol.App.Sci. 6(12): 1627-1637.

doi: https://doi.org/10.20546/ijcmas.2017.612.183 